\title{
ANALISA YURIDIS \\ PENCANTUMAN KLAUSUL KUASA MUTLAK DI DALAM PERJANJIAN HIBAH
}

\author{
Hanung Widjangkoro \\ Fakultas Hukum Universitas Wijaya Kusuma Surabaya \\ e-mail: hwidjangkoro@gmail.com
}

\begin{abstract}
ABSTRAK
Pendaftaran tanah diselenggarakan dalam rangka memberi jaminan kepastian hukum. Dalam hal melakukan hukum untuk mengalihkan suatu hak atas tanah haruslah dilakukan di hadapan seorang Notaris atau Pejabat Pembuat Akta Tanah yang bertujuan untuk memperoleh kekuatan pembuktian yang sah dan dibuatkan dengan akta otentik. Khusus untuk tanah-tanah yang bersertipikat dalam proses pengalihan hak ini harus dilakukan di hadapan Pejabat Pembuat Akta Tanah, dalam pelaksanaan peralihan hak atas tanah dengan Perjanjian Hibah/Perikatan Hibah. Dalam pembuatan Perjanjian hibah sering dicantumkan kuasa mutlak yang merupakan perjanjian pendahuluan yang lazim ditemukan dalam praktek Notaris. Kuasa mutlak terdapat pada perjanjan hibah ini sebagai tindak lanjut dari perjanjian pendahuluan dalam peralihan hak atas tanah masih dapat diberlakukan untuk menjaga kepentingan para pihak dapat terpenuhi hingga proses peralihan hak atas tanah tersebut selesai.
\end{abstract}

Kata Kunci: peralihan hak atas tanah, kuasa mutlak, hibah.

\section{ABSTRACT}

Registration of land held in order to ensure legal certainty. In terms of doing the law to transfer a land rights should be conducted in the presence of a Notary Public or a Land Deed Official aiming to obtain the strength of evidence that are legitimate and made with authentic deed. Especially for the certified lands in the process of transfer of these rights must be carried out in the presence of the Land Deed Official, in the implementation of transitional land rights with the Grant Agreement/Engagements grants. In making the grant agreement is often included absolute power is a preliminary agreement that is commonly found in practice Notary. Absolute power contained in the grant agreement as a follow up of a preliminary agreement in the turnover of land rights can still be enacted to safeguard the interests of the parties can be fulfilled until the transition process is completed the land rights.

Keywords: transfer of rights over land, absolute power, grant.

\section{PENDAHULUAN}

Peranan tanah sebagai pemenuhan kebutuhan masyarakat sangatlah penting, maka masyarakat menuntut adanya jaminan kepastian hukum atas bidang tanah tersebut. Untuk mendapatkan jaminan kepastian hukum atas bidang tanah, memerlukan perangkat hukum yang tertulis.

Negara mempunyai kewajiban untuk mengatur pemilikan tanah dan penggunaan atas tanah, hingga semua tanah di seluruh wilayah kedaulatan negara Indonesia dapat dipergunakan untuk sebesar-besar kemakmuran rakyat Indonesia, sehingga pemerintah Indonesia dalam penyusunan hukum agraria nasional untuk sebuah jaminan kepastian hukum atas tanah tersebut.

Dalam rangka menuju terwujudnya kepastian hukum terhadap hak-hak atas tanah dilakukan pendaftaran hak atas tanah. Dibutuhkan suatu pendaftaran tanah yang diatur oleh Undang-Undang Nomor 5 Tahun 1960 tentang Peraturan Dasar PokokPokok Agraria (yang selanjutnya disebut UUPA). Sebagai konsistensi dari pemerintah terhadap UUPA untuk menjamin kepastian hukum terhadap tanah. Maka pemerintah membuat Peraturan Pemerintah Nomor 24 Tahun 1997 tentang Pendaftaran Tanah. 
Pendaftaran tanah diselenggarakan dalam rangka memberi jaminan kepastian hukum di bidang pertanahan dan bahwa sistem publikasi ini sangat penting bagi pemilikan dan penguasaan sebidang tanah karena pendaftaran tanah ini akan menghasilkan surat-surat tanda bukti hak yang berlaku sebagai alat pembuktian yang kuat dalam pemilikan dan penguasaan sebidang tanah, seperti yang dinyatakan dalam Pasal 19 ayat (2) huruf C, Pasal 23 ayat (2), dan Pasal 38 ayat (2) oleh UUPA.

Dalam rangka menuju terwujudnya kepastian hukum terhadap peralihan hak atas tanah meliputi pemindahan hak atas tanah. Dapat dilakukan proses pendaftaran hak atas tanah. Namun dalam praktek sering ditemui kenyataan bahwa orangorang menyamakan pengertian peralihan dengan pemindahan hak atas tanah. Perbuatan hukum pemindahan hak atas tanah, berarti hak atas tanah yang bersangkutan sengaja dialihkan kepada pihak lain. Adapun bentuk pemindahan haknya adalah sebagai berikut: 1. Jual beli; 2. Tukar menukar; 3. Hibah; 4. Pemberian menurut hukum adat; 5. Pemasukan dalam perusahaan atau inbreng; dan 6. Hibah wasiat. ${ }^{1}$

Pemindahan hak atas tanah dengan akta Hibah merupakan salah satu perbuatan hukum yang menyebabkan terjadinya pemindahan hak atas tanah. Pemindahan hak atas tanah dengan akta Hibah merupakan pemberian seseorang kepada orang lain dengan tidak ada penggantian apa pun dan dilakukan secara suka rela, tanpa ada kontraprestasi dari pihak pemenerima pemberian dan pemberian itu dilangsungkan pada saat si pemberi masih hidup.

Pengertian hibah menurut Pasal 1666 KUHPerdata yakni sesuatu perjanjian dengan mana si penghibah di waktu hidupnya dengan cuma-cuma dan dengan tidak dapat ditarik kembali menyerahkan sesuatu benda guna keperluan si penerima hibah yang menerima penyerahan itu. Sebelumnya lahir PP No. 24 Tahun 1997, bagi mereka yang tunduk kepada KUHPerdata.

Proses pembuatan akta hibah tanah dibuat dan menghadap notaris dapat dilakukan oleh si penerima hibah sendiri atau oleh seorang kuasa yang dikuasakan dengan akta otentik (akta notaris). Sesuai dengan KUHPerdata Pasal 1792 yang dimaksud dengan pemberian kuasa yaitu penerima kuasa

\footnotetext{
${ }^{1}$ Boedi Harsono, Hukum Agraria Indonesia-Sejarah Pembentukan Undang-Undang Pokok Agraria, Isi dan Pelaksanaannya, Djambatan, Jakarta, 2005, h. 333.
}

diberi wewenang untuk mewakili pemberi kuasa dalam melakukan tindakan hukum dari pemberi kuasa. Penerima kuasa perlu diperhatikan mengingat berakhirnya suatu kuasa sebagaimana diatur dalam Pasal 1813 KUHPerdata yaitu Kuasa ditarik kembali oleh pemberi kuasa, pemberi kuasa Pemberitahuan penghentian kuasa dan pemberi kuasa Meninggal.

Dalam perkembangannya dewasa ini pemindahan hak atas tanah dalam proses pembuatan perjanjian hibah di notaris sering mencantum klausula kuasa mutlak. Surat kuasa mutlak tersebut menurut sifatnya tidak dapat dicabut kembali bahkan tidak akan berakhir. Biarpun bertentangan dengan Pasal 1813 KUHPerdata tetapi notaris mempunyai analisa hukum yang berbeda sehingga notaris berani membuat kuasa mutlak tercantum dalam akta perjanjan hibah yang tidak diatur di KUHPerdata. Tetapi kuasa mutlak terdapat dalam klausul perjanjian hibah merupakan satu kesatuan dari perjanjian pokoknya yaitu perjanjian hibah yang tidak terpisahkan. Kuasa mutlak sangat dibutuhkan untuk melindungi para pihak yang mempunyai itikad baik dalam melaksanakan perbuatan hukum di akta perjanjian hibah tersebut. Kuasa mutlak dalam akta perjanjian hibah untuk mewujudnya kepastian hukum terhadap proses pemindahan hak atas tanah di pendaftaran tanah.

Berdasarkan uraian di atas, perumusan masalah yang timbul adalah karakteristik pencantuman klausul kuasa mutlak di dalam akta perjanjian hibah di notaris, dan pencantuman kuasa mutlak pada akta perjanjian hibah di notaris tidak bertentangan dengan peraturan perundangan yang berlaku.

\section{PEMBAHASAN}

\section{Karakteristik Pencantuman Klausul Kuasa Mutlak di Dalam Akta Perjanjian Hibah di Notaris}

Hibah dalam hukum positif diatur dalam Kitab Undang-Undang Hukum Perdata, Pasal 1666 menegaskan bahwa hibah merupakan suatu perjanjian dengan mana si penghibah, di waktu hidupnya, dengan cuma-cuma dan dengan tidak dapat ditarik kembali, menyerahkan sesuatu benda guna keperluan si penerima hibah yang menerima penyerahan itu. Undang-undang tidak mengakui lain-lain hibah-hibah di antara orang-orang yang masih hidup.

Hibah harus dibuat dengan akta notaris sesuai dengan ketentuan yang tercantum dalam Pasal 1682 KUHPerdata menegaskan tiada suatu penghibahan pun kecuali termaksud dalam Pasal 1687 dapat 
dilakukan tanpa akta notaris, yang minut atau naskah aslinya harus disimpan pada notaris dan bila tidak dilakukan demikian maka penghibahan itu tidak sah.

Notaris dalam melaksanakan tugas dan jabatannya dalam membuat akta perjanjian harus berhati-hati dan teliti, agar akta yang dibuatnya tidak cacat hukum pada kemudian hari, karena Notaris dalam melaksanakan tugas dan jabatannya harus dipertanggungjawabkan kepada masyarakat umum dan juga supaya tidak merugikan kepentingan pihak lain. Setiap produk akta perjanjian yang dibuat oleh notaris, khususnya sangat rentang timbul konflik.

Konflik yang timbul dari hasil produk hukum berupa akta perjanjian yang dibuat oleh notaris sering terjadi adanya kesalahpahaman antara para pihak yang melakukan perjanjian. Untuk menghindari sering terjadi kesalahpahaman terhadap menafsirkan dan melaksanan akta perjanjian sudah dibuat oleh para pihak di notaris. Maka notaris dalam membuat akta perjanjian harus berhati-hati dan teliti, agar akta yang dibuatnya tidak cacat hukum pada kemudian hari. Dalam suatu akta perjanjian, ada pasal atau bagian dari asal yang hendaknya mengatur suatu hal tertentu yang bersifat khusus berkaitan dengan kemungkinankemungkinan peristiwa yang tidak pernah dikehendaki oleh para pihak di kemudian hari. Walaupun dalam undang-undang sudah dinyatakan dengan tegas terkait ketentuan-ketentuan yang harus dipenuhi, namun dalam proses pelaksanaan pembuatan akta perjanjian khususnya akta perjanjian hibah banyak ketentuan-ketentuan dalam undang-undang tersebut yang tidak dijelaskan secara detail dan rinci. Dalam klausula-klausula yang ada dalam akta perjanjian hibah pada umumnya, ketika diimplementasikan dalam masyarakat, banyak kemungkinan konflik dan kesalahpahaman yang akan timbul. Hal ini disebabkan karena notaris dalam membuat akta perjanjian hibah, umumnya hanya memuat klausula-klausula baku yang belum mengakomodir kepentingan para pihak.

Tata cara penghibahan harus melalui suatu akta autentik dilakukan pada waktu pemberi hibah masih hidup kepada penerima hibah, sehingga perjanjian hibah ini akan berlaku sejak hari penerimaan hibah itu diberitahukan penerima hibah. Untuk menjamin perbuatan-perbuatan dan keterangan kehendak mereka untuk di kemudian hari dan dalam suatu bentuk demikian yang dapat dibuat, akan menghadap ke muka notaris dengan maksud supaya dibuatkan dalam bentuk tulisan mengenai perbuatan-perbuatan atau keterangan kehendak mereka itu dalam bentuk akta yang mempunyai kekuatan otentisitas. ${ }^{2}$

Mengenai dasar hukum pemberian kuasa pada awalnya dijumpai dalam Pasal 35 Undang-Undang No. 14 Tahun 1970 tentang Ketentuan-Ketentuan Pokok Kekuasaan Kehakiman, yang menjelaskan pemberian kuasa disebutkan secara tersirat dan konkritnya disebut sebagai bantuan hukum. Pengertian pemberian kuasa dapat dijumpai pada Pasal 1792 KUHPerdata yang menentukan bahwa: Pemberian kuasa adalah suatu perjanjian dengan mana seorang lain memberikan kekuasaan kepada seorang lain, yang menerimanya untuk atas namanya, menyelenggarakan suatu urusan.

Pemberian kuasa atau lastgeving juga diatur dalam buku III Bab XVI mulai dari Pasal 1792-1819 KUHPerdata, kuasa atau volmacht sendiri tidak diatur secara khusus dalam KUHPerdata maupun di dalam peraturan perundang-undangan lainnya, akan tetapi diuraikan sebagai salah satu bagian dari pemberian kuasa. Pasal 1792 KUHPerdata menunjukkan bahwa sifat pemberian kuasa tidak lain dari mewakilkan atau perwakilan atau vertegenwoordiging.

Pemberian kuasa sebagai wakil yang dibuat melalui persetujuan selalu disebut kuasa atau volmacht. ${ }^{3}$ Pada dasarnya kuasa inilah yang menjadi tujuan dari persetujuan pemberian kuasa tersebut yang kemudian dimasukkan sebagai klausula dalam suatu akta notariil. Pada perkembangan dewasa ini pemberian kuasa sangat luas akan tetapi semua itu tidak dibahas dalam tulisan ini, hanya pemberian kuasa mutlak dalam pada klausula akta perjanjian hibah di Notaris yang berkembang dalam kehidupan masyarakat yang berkaitan dengan kepentingan masyarakat dalam melakukan suatu perbuatan hukum dalam perjanjian hibah mengenai khususnya dalam peralihan hak atas tanah.

Pencantuman kuasa mutlak pada kluasula akta perjanjian hibah di Notaris tidak dijumpai aturannya di dalam KUHPerdata namun diatur dalam Yurisprudensi Mahkamah Agung (yang selanjutnya disebut MA) antara lain pada: Putusan MA tanggal 16 Desember 1967 No. 731 K/Sip/1975; dan Putusan MA tanggal 17 Nopember 1987 No. 3604 K/Pdt/1985.

${ }^{2}$ Muhammad Adam, 1985, Asal Usul dan Sejarah Akta Notarial, Sinar Baru, Bandung, h. 31.

${ }^{3}$ Sri Gambir Melati Hatta, 1999, Beli Sewa Sebagai Perjanjian Tak Bernama: Pandangan Masyarakat dan Sikap Mahkamah Agung Indonesia, Alumni, Bandung, h. 264. 
Dalam Putusan MA mengakui keberadaannya kuasa mutlak sebagai suatu kebutuhan hukum. Putusan MA tanggal 16 Desember 1967 No. 731 K/ Sip/1975 telah menegaskan bahwa ketentuan Pasal 1813 KUHPerdata tidak bersifat limitatif dan tidak mengikat oleh karena itu jika sifat perjanjian memang menghendaki, dapat ditentukan pemberian kuasa mutlak tidak dapat dicabut kembali.

Pemberian kuasa mutlak merupakan suatu perikatan yang muncul dari perjanjian, yang diatur Pasal 1338 KUHPerdata, yang mengakui adanya kebebasan berkontrak, dengan pembatasan bahwa perjanjian tidak boleh bertentangan dengan peraturan perundang-undangan dan harus dilandasi dengan itikad baik.

Peraturan perundangan dimaksud adalah Pasal 1320 KUHPerdata tentang syarat sahnya perjanjian, Pasal 1138 KUHPerdata tentang pembatasan dari asas kebebasan berkontrak, Pasal 1813 KUHPerdata tentang berakhirnya pemberian kuasa, Peraturan Pemerintah Nomor 24 Tahun 1997 tentang Pendaftaran Tanah khususnya Pasal 37, Pasal 38, Pasal 39, serta Instruksi Menteri Dalam Negeri Nomor 14 Tahun 1982 tentang Larangan Penggunaan Kuasa Mutlak, Surat Dirjen Agraria, Menteri Dalam Negeri RI Nomor 594/493/AGR, tanggal 31 Maret 1982. Serta dalam hal mengenai klausul pemberian kuasa mutlak, seperti dinyatakan dalam Instruksi Menteri Dalam Negeri Nomor 14 Tahun 1982, yang dimaksud dengan Kuasa Mutlak merupakan yang didalamnya mengandung unsur tidak dapat ditarik kembali oleh pemberi kuasa.

Latar belakang dikeluarkannya Instruksi tersebut adalah adanya penyalahgunaan Kuasa Mutlak diantaranya terhadap ketentuan mengenai penetapan luas tanah pertanian yang tercantum dalam UndangUndang Nomor 5 Tahun 1960, pemilikan atas tanah hak oleh subjek hukum tertentu menurut UndangUndang Nomor 5 Tahun 1960 tentang Peraturan Dasar Pokok Agraria atau ketentuan mengenai pengenaan pajak atas tanah.

Namun apabila dihubungkan dengan syaratsyarat sahnya suatu perjanjian sebagaimana yang telah diuraikan sebelumnya dan ditilik dari rasa keadilan dan asas keseimbangan dalam berkontrak serta kebutuhan masyarakat dalam praktek. Kuasa mutlak pada hakikatnya dapat dilaksanakan bila klausula kuasa mutlak merupakan suatu kesatuan dalam klasula perjanjian hibah. Di dalam perjanjian hibah ini kuasa mutlak terletak pada Pasal 5 yaitu Kuasa yang tersebut dalam perjanjian ini tidak dapat ditarik kembali dan merupakan bagian yang tidak dapat dipisahkan dari perjanjian ini yang tanpa kuasa tersebut tidak akan dibuat dan kuasa itu pun diberikan dengan melepaskan segala peraturan yang ditetapkan dalam undang-undang yang mengatur segala sebabsebab dan dasar yang mengakhiri sesuatu kuasa pada umumnya, dan Pasal 7 yaitu Perjanjian ini tidak berakhir, jika salah satu pihak meninggal dunia, akan tetapi turun temurun dan harus dipenuhi oleh ahli waris masing-masing. Kuasa mutlak ini memberikan keuntungan bagi pihak penerima hibah di mana penerima hibah akan merasa aman dengan adanya perjanjian hibah dan kuasa mutlak ini. Mengingat alasan mengapa kuasa mutlak itu diberikan, dalam kasus ini kuasa mutlak tersebut diberikan dengan alasan: Pemberi kuasa tidak dapat hadir dalam proses peralihan hak atas tanah; Pemberi kuasa meninggal sebelum proses peralihan hak atas tanah itu selesai.

Namun dalam hal ini, kuasa mutlak itu sendiri tidak ada peraturan khusus yang mengaturnya. Akan tetapi timbul akibat dari Pasal 1338 ayat (1) KUHPerdata yang menegaskan bahwa semua perjanjian yang dibuat secara sah berlaku sebagai undang-undang bagi mereka yang membuatnya. Pasal ini lebih dikenal sebagai dasar dari kebebasan membuat perjanjian/kebebasan berkontrak.

Berdasarkan ketentuan Pasal 1813 KUHPerdata yang menegaskan bahwa pemberian kuasa berakhir dengan ditariknya kembali kuasa si penerima kuasa, jika dikaitkan dengan klausul pemberian kuasa pada perjanjian hibah yang merupakan kuasa mutlak atau kuasa yang tidak dapat dicabut kembali, maka jelas bahwa klausul tersebut bertentangan dengan undang-undang yang ada. Hal ini juga dijelaskan pada Pasal 1814 KUHPerdata tentang adanya hak dari pemberi kuasa untuk dapat menarik kembali kuasanya manakala dikehendaki.

Namun demikian jika Instruksi Menteri Dalam Negeri Nomor 14 Tahun 1982 tentang Larangan Penggunaan Kuasa Mutlak Sebagai Pemindahan Hak Atas Tanah, apabila dikembalikan pada undangundang yaitu Pasal 1792 KUHPerdata tentang pemberian kuasa atau last geving, khususnya pada Pasal 1813 KUHPerdata serta, tentang berakhirnya suatu pemberian kuasa, apabila dikaitkan dengan Pasal 1338 KUHPerdata tentunya para pihak dapat memperjanjikan. 
Berlakunya asas kebebasan berkontrak dalam hukum perjanjian Indonesia antara lain dapat disimpulkan dari Pasal 1338 KUHPerdata menyatakan bahwa: semua perjanjian yang dibuat secara sah berlaku sebagai undang-undang bagi mereka yang membuatnya. Dalam pasal ini tersirat adanya bahwa antara para pihak harus ada suatu kesepakatan. Dengan demikian bahwa kebebasan berkontrak berkaitan erat dengan asas konsensualisme atau sepakat antara para pihak yang membuat perjanjian. Tanpa adanya sepakat dari salah satu pihak yang membuat perjanjian, maka perjanjian itu yang dibuat adalah tidak sah.

Kebebasan berkontrak atau kebebasan membuat perjanjian tidaklah sebebas-bebasnya dibuat oleh para pihak. Hal ini dapat disimpulkan dari Pasal 1320 ayat (4) jo Pasal 1337 jo Pasal 1338 ayat (3). Pasal 1339 KUHPerdata bahwa mengenai kuasa yang dilarang oleh undang-undang atau bertentangan dengan kesusilaan baik, kepatutan atau ketertiban umum dan undang-undang. Artinya bahwa bila dilihat dari pasal KUHPerdata ternyata asas kebebasan berkontrak itu bukannya bebas mutlak. Ada beberapa pembatasan yang diberikan oleh KUHPerdata terhadap asas ini yang membuat asas ini merupakan asas yang terbatas atau perjanjian yang berat sebelah atau timpang.

Pasal 1320 ayat (4) KUHPerdata menentukan bahwa para pihak tidak bebas untuk membuat perjanjian yang menyangkut causa yang dilarang oleh undang-undang atau bertentangan dengan kesusilaan atau ketertiban umum. Pasal 1337 KUHPerdata yang dengan tegas menyatakan bahwa suatu sebab adalah terlarang, apabila dilarang oleh undang-undang, atau apabila berlawanan dengan kesusilaan baik atau ketertiban umum. Pasal 1338 ayat (3) KUHPerdata memberikan arah mengenai kebebasan pihak untuk membuat perjanjian sepanjang dilakukan dengan itikad baik.

Pasal 1339 KUHPerdata menerangkan salah satu batasan bagaimana perjanjian itu dapat mengikat kedua belah pihak walaupun telah dinyatakan dengan tegas didalamnya apa-apa yang diperjanjikan, yaitu mengenai dan untuk segala sesuatu yang menurut sifat persetujuan, diharuskan oleh kesusilaan, kebiasaan atau undang-undang.

Perihal sahnya suatu perjanjian, maka syarat mutlak yang harus ada dalam perjanjian pemberian kuasa adalah persetujuan para pihak untuk melakukan perjanjian pemberian kuasa, maka dalam hal ini peranan Notaris dalam melaksanakan tugas jabatannya berkewajiban untuk memberikan peneranganpenerangan yang lengkap dan jelas mengenai akibat-akibat hukum dari tiap-tiap perjanjian yang dibuatnya, serta dalam hal memberikan pelayanan dan jasa kepada pihak-pihak sejauh mungkin menghindarkan terjadinya sengketa dikemudian hari agar terciptanya suatu kepastian hukum khususnya di bidang pertanahan sesuai dengan peraturan pemerintah yang berlaku.

Menurut pendapat Notaris Liliana Tedjosaputro, yaitu: pada satu sisi memang larangan penggunaan kuasa mutlak tersebut bertentangan dengan azas kebebasan berkontrak. Akan tetapi pelarangan tersebut adalah dalam hal surat kuasa mutlak tersebut berdiri sendiri. Dikatakan surat kuasa mutlak tersebut berdiri sendiri adalah bilamana kuasa mutlak tersebut bukan bagian dari suatu perjanjian pokok, misalnya perjanjian pengikatan jual beli. Surat kuasa mutlak yang dibuat berdiri sendiri dalam pengalihan hak atas tanah berpotensi terjadi penyimpangan dan adanya itikad tidak baik dalam pemberian kuasa tersebut, oleh karenanya dikeluarkan larangan tersebut, dan hal ini bukanlah pelanggaran dari azas kebebasan berkontrak. $^{4}$

Kuasa mutlak tersebut merupakan bagian dari perjanjian pokoknya tersebut. Kuasa mutlak tersebut tidak dapat dibatalkan secara sepihak sebelum perjanjian pokoknya dibatalkan. Oleh karenanya kuasa yang merupakan bagian dari perjanjian tersebut adalah sebagai jaminan kepastian hukum telah terjadi perbuatan hukum dalam perjanjian hibah dan menjamin kepastian hukum bagi menerima hibah bilamana pihak pemberi hibah meninggal dunia, penerima kuasa tetap dapat menjalankan proses pembuat akta hibah di hadapan Pejabat Pembuat Akta Tanah (yang selanjutnya disebut PPAT).

\section{Pencantuman Klausul Kuasa Mutlak di dalam Akta Perjanjian Hibah di Notaris}

Pokok permasalahan yang terakhir, apakah mencantumkan kuasa mutlak pada akta perjanjian hibah di notaris tidak bertentangan dengan peraturan perundangan yang berlaku. Seperti telah dijelaskan di atas, bahwa Akta Perjanjian Hibah merupakan

${ }^{4}$ Ronny Utama, Tesis, tentang Larangan Kuasa Mutlak Notariil, Universitas Diponegoro, Semarang, h. 101, available from http://core.ac.uk/download/pdf/11715805.pdf., diakses tanggal 11 Oktober 2015. 
tahap awal sebelum dilakukan perbuatan hukum akta hibah PPAT. Untuk memenuhi ketentuan Pasal 37 PP No. 24 Tahun 1997 tersebut, maka akta perjanjian hibah notaris tersebut harus ditindaklanjuti dengan perbuatan hukum yang dilakukan di hadapan PPAT yang berwenang dengan membuat apa yang disebut dengan akta hibah, yang fomulirnya telah ditetapkan oleh Menteri. Demikian dengan dibuatnya akta hibah, maka perbuatan hukum pemindahan hak tersebut dapat didaftarkan di Kantor Pertanahan setempat.

Prosedur Pembuatan Formulir Akta Hibah ada istilah Komparisi/tindakan menghadap yaitu Pencantuman nama lengkap, pekerjaan atau jabatan (sepanjang hal ini dapat diberitahukan) dan tempat tinggal setiap penghadap dan (bila ada) yang diwakilinya merupakan keharusan dalam akta hibah. Jika penghadap bukan pemilik obyek hibah dan hanya bertindak selaku kuasa atau dalam jabatan dari orang atau badan hukum atau instansi yang mewakilinya, maka kualitas atau dasar hukum dari tindakannya harus disebutkan secara jelas; Surat kuasa yang tidak otentik harus dilekatkan atau dijahitkan pada akta yang disimpan oleh pejabat: notaris, PPAT, atau pejabat umum, dan harus disebutkan dalam aktanya. Demikian pula nama-nama orang atau badan hukum atau instansi yang mewakilinya diuraikan secara lengkap.

Setelah lahirnya PP No. 24 Tahun 1997, setiap pemberian hibah tanah harus dilakukan dengan akta PPAT. Perolehan tanah dengan hibah harus didaftarkan di Kantor Pertanahan untuk memperoleh kepastian hukum. Sehingga akta perjanjian hibah harus dibuatkan akta hibah PPAT.

PPAT melakukan tugasnya membuat akta hibah guna memindahkan hak milik atas tanah yang diminta kepadanya, maka terlebih dahulu ia meneliti subyek dan obyek penghibahan tersebut, sehingga PPAT tidak dapat dengan mudah membuat akta hibah, karena apabila terjadi suatu kekeliruan atau pelanggaran ia dapat dituntut atas kerugian yang timbul karenanya.

Jika dilihat dari pendapat Ali Boediarto yang pada intinya memberi pertimbangan sebagai berikut: "Menurut pendirian Mahkamah Agung RI: adalah merupakan perbuatan yang sah menurut hukum, bahwa seseorang pemilik tanah yang mengalihkan haknya/kekuasaannya atas tanah yang dimilikinya itu kepada pihak lain, melalui cara pembuatan Kuasa Mutlak di mana pihak penerima kuasa menjadi berhak dan berkuasa penuh atas tanah tersebut, seperti halnya seorang pemilik dan ia dapat menuntut pihak ketiga yang dinilai mengganggu haknya itu". ${ }^{5}$

Pembuatan Kuasa Mutlak seperti yang diuraikan di atas mengandung materi, bahwa pemilik tanah selaku Pemberi Kuasa memberi kuasa penuh kepada Penerima Kuasa untuk menguasai dalam arti luas, yaitu mengasingkan atau vervreenden dan/atau melakukan perbuatan hukum macam apapun juga terhadap tanah yang bersangkutan, seperti halnya seorang yang berstatus sebagai pemilik tanah. Kuasa mutlak ini tidak dapat dicabut kembali. ${ }^{6}$

Sebagaimana diatur dalam Pasal 1813 KUH Perdata menegaskan bahwa kuasa akan berakhir apabila: Kuasa ditarik kembali, Pemberitahuan penghentian kuasa dam Meninggalnya pengampu atau pailitnya pemberi kuasa atau yang menerima kuasa, serta Perkawinan perempuan yang sudah memberikan kuasa atau yang menerima kuasa (untuk ketentuan terakhir ini sudah tidak berlaku lagi).

Oleh karena itu pemberian kuasa yang dimaksud dalam Pasal 1792 KUHPerdata tidaklah dapat dilepaskan dari isi Pasal 1813 KUHPerdata tersebut. Artinya bahwa apabila unsur-unsur yang terdapat dalam Pasal 1813 KUHPerdata tersebut terpenuhi maka perjanjian pemberian kuasa yang dibuat berakibat tidak berkekuatan hukum lagi.

Namun demikian perlu diperhatikan, bahwa pemberian kuasa tersebut hanya meliputi tindakan pengurusan saja. Dan hal ini tersirat pada Pasal 1792 KUHPerdata dan ditegaskan pada Pasal 1797 KUHPerdata bahwa si penerima kuasa tidak boleh melakukan sesuatu apapun yang melampaui batas kuasanya. Maksudnya disini adalah bahwa penerima kuasa tidak diperbolehkan melakukan segala perbuatan hukum yang menurut hukum hanya dapat dilakukan oleh si pemberi kuasa dalam hal ini adalah pemilik atau pemegang haknya.

Isi Instruksi Menteri Dalam Negeri No. 14 Tahun 1982 tersebut antara lain adalah menginstruksikan kepada semua Gubernur/Kepala Daerah Tingkat I dan para Bupati/Walikota Kepala Daerah Tingkat II untuk melarang: a. Camat dan Kepala Desa atau pejabat yang setingkat dengan itu untuk membuat/ menguatkan pembuatan surat kuasa mutlak yang pada hakekatnya merupakan pemindahan hak atas tanah; b. Pejabat-pejabat agraria untuk melayani penyelesaian

\footnotetext{
5 Ali Boediarto, "Putusan Badan Peradilan", Majalah Varia Peradilan, Edisi Oktober, Jakarta, 1990, h. 11.

${ }^{6}$ Ibid.
} 
status hak atas tanah yang merupakan surat kuasa mutlak sebagai bahan pembuktian pemindahan hak atas tanah.

Berdasarkan Instruksi Menteri Dalam Negeri tersebut dapat disimpulkan bahwa kuasa mutlak mempunyai 3 (tiga) unsur, yaitu obyek dari kuasa tersebut adalah tanah dan kuasa tersebut mengandung unsur tidak dapat ditarik kembali oleh pemberi kuasa, serta kuasa tersebut memberikan kewenangan kepada penerima kuasa untuk menguasai dan menggunakan tanah serta melakukan segala perbuatan hukum yang menurut hukum hanya dapat dilakukan oleh pemegang haknya, dan pada hakekatnya merupakan suatu pemindahan hak atas tanah.

Pemberian suatu kuasa mutlak dapat menimbulkan konflik antara lain adanya ketidakseimbangan antara hak dan kewajiban dari para pihak. Hal ini disebabkan karena bahwa pemberian kuasa mutlak ditujukan untuk kepentingan pihak penerima kuasa, dan penyalahgunaan klausul kuasa mutlak yang tidak dapat dicabut kembali. Karena pemberian kuasa tersebut dapat melakukan tindakan pemilikan dan tindakan pengurusan tanpa persetujuan dari pemberi kuasa dan ini sangat merugikan pihak pemberi kuasa karena tidak bisa berbuat apa-apa. Hal ini juga merupakan perbuatan melanggar hukum dari penerima kuasa karena telah melampaui batas-batas kuasanya.

Permasalahan sekarang apakah kuasa mutlak yang diberikan dalam perjanjian hibah ini pada proses peralihan haknya tidak bertentangan dengan Pasal 39 huruf d PP Nomor 24 Tahun 1997, hal ini dapat penulis menjelaskan, bahwa kuasa tersebut di dalam akta perjanjian hibah notaris merupakan bagian yang tidak terpisahkan dari akta perjanjian hibah atau dan perjanjian pokoknya, yang mana apabila perjanjian pokok tersebut telah terpenuhi dengan ketentuan, di mana tinggal kepentingan yang menerima kuasa, atau syarat formal telah terpenuhi akan ditindak lanjuti dengan perbuatan hukum yang dilakukan di hadapan PPAT yang berwenang.

Larangan terhadap kuasa mutlak sebagaimana yang disebutkan dalam Instruksi Menteri Dalam Negeri Nomor 14 Tahun 1982 tentang Larangan Penggunaan Kuasa Mutlak Sebagai Pemindahan Hak Atas Tanah yang dimaksud, adalah perjanjian pemberian yang tidak mengikuti perjanjian pokoknya. Di mana hal ini telah tersirat dalam Surat Dirjend.
Agraria atas nama Menteri Dalam Negeri Republik Indonesia No. 594/493/AGR, tanggal 31 Maret 1982.

Dengan demikian, tidak bertentangan dengan Pasal 37 PP No. 24 Tahun 1997 yang menentukan bahwa pengalihan hak atas tanah harus dibuktikan dengan akta yang dibuat oleh PPAT yang berwenang. Dan juga dapat ditegaskan bahwa kuasa yang demikian tidaklah merupakan kuasa mutlak yang dilarang sebagaimana dinyatakan dalam Instruksi Menteri Dalam Negeri Nomor 14 Tahun 1982 tentang Larangan Penggunaan Kuasa Mutlak Sebagai Pemindahan Hak Atas Tanah.

Sedangkan klausul pemberian kuasa mutlak berkaitan dengan ketentuan Pasal 39 PP No. 24 Tahun 1997 mengenai kewenangan PPAT dalam menolak pembuatan Akta perjanjian hibah, di mana dalam ayat (1) huruf d yang menegaskan, bahwa PPAT menolak untuk membuat akta jika salah satu pihak atau para pihak bertindak atas dasar suatu surat kuasa mutlak yang pada hakekatnya berisikan perbuatan hukum pemindahan hak.

Bahwa apa yang dimaksud dalam Pasal 39 ayat (1) huruf d tersebut adalah pemberian kuasa mutlak yang dilarang sebagaimana dinyatakan dalam Instruksi Menteri Dalam Negeri Nomor 14 Tahun 1982 tentang Larangan Penggunaan Kuasa Mutlak Sebagai Pemindahan Hak Atas Tanah.

Larangan tersebut ditujukan kepada kuasa mutlak yang berdiri sendiri. Kuasa mutlak yang berdiri sendiri dalam pengalihan hak atas tanah memberikan kewenangan kepada penerima kuasa untuk menguasai dan menggunakan tanahnya serta melakukan segala perbuatan hukum yang menurut hukum hanya dapat dilakukan oleh pemegang haknya. Kuasa mutlak yang berdiri sendiri ini tidak ada batasan berakhirnya, sehingga dapat terus digunakan oleh pihak penerima kuasa, hal ini dapat menimbulkan penyalahgunaan kewenangan.

Sedangkan kuasa mutlak yang terdapat di dalam perjanjian yang dibuat oleh notaris yang merupakan bagian dari perjanjian pokok tidak dilarang oleh Instruksi Menteri Dalam Negeri Nomor 14 Tahun 1982 tentang Larangan Penggunaan Kuasa Mutlak Notariil dalam Pengalihan Hak Atas Tanah dan Peraturan Perundangan Agraria yang Berlaku.

Instruksi Menteri Dalam Negeri Nomor 14 Tahun 1982 menjelaskan tentang bentuk khusus dalam pemberian kuasa, yang hal ini jika dikaitkan dengan PP Nomor 24 Tahun 1997 tentang Pendaftaran 
Tanah Pasal 39 dan Pasal 1813 KUHPerdata jelas merupakan penyimpangan dan bertentangan dengan peraturan perundangan yang berlaku. Namun perlu diperhatikan, bahwa hal ini tidak dapat dilepaskan dari Diktum Kedua huruf b dari Instruksi Menteri Dalam Negeri tersebut, yang intinya adalah menyatakan bahwa larangan tersebut bagi kuasa mutlak yang pada hakekatnya merupakan pemindahan hak atas tanah yang memberikan kewenangan kepada penerima kuasa untuk menguasai dan menggunakan tanahnya serta melakukan segala perbuatan hukum yang menurut hukum hanya dapat dilakukan oleh pemegang haknya.

Perlu diperhatikan lagi bahwa, larangan penggunaan kuasa mutlak sebagai pemindahan hak atas tanah yang dimaksud, adalah perjanjian pemberian yang tidak mengikuti perjanjian pokoknya. Di mana hal ini telah tersirat dalam Surat Dirjend. Agraria atas nama Menteri Dalam Negeri Republik Indonesia No. 594/493/AGR, tanggal 31 Maret 1982. Sebagai contoh, bahwa dalam Surat Kuasa Memasang Hipotik yang sekarang disebut dengan Surat Kuasa Membebankan Hak Tanggungan (SKMHT) yang merupakan bagian dan sebagai tindakan awal pengamanan/perlindungan bagi kreditur terhadap Surat Pengakuan Hutang yang dibuat, dicantumkan klausul tidak dapat dicabut dan tidak akan berakhir karena sebab apapun juga, yang mana hal ini hanya bersifat sementara sampai hutangnya lunas.

Demikian juga dalam Perjanjian Hibah, di mana perjanjian pemberian kuasa di dalamnya harus diberikan dengan ketentuan bahwa kuasa tersebut merupakan bagian yang tidak terpisahkan dari perjanjian pokoknya yaitu perjanjian hibah itu sendiri. Dengan demikian perjanjian pemberian kuasa yang demikian tidak termasuk dalam surat kuasa mutlak yang dilarang. Dengan catatan bahwa kuasa yang diberikan di dalam perjanjian hibah yang dibuat secara notaril di mana hak-hak pemberi kuasa sudah terpenuhi.

Kuasa mutlak sebagai tindak lanjut dari perjanjian pendahuluan dalam peralihan hak atas tanah masih dapat diberlakukan karena belum terpenuhinya syarat-syarat untuk melangsungkan perjanjian hibah dihadapan PPAT. Para pihak yaitu pihak pemohon hibah untuk sementara dapat menunda pembayaran pajak sampai batas yang dikehendaki mereka atas Pajak Penghasilan (PPh) yang diwajibkan oleh pemohon hibah berdasarkan Undang-Undang No.
17 Tahun 2000 bagi pihak pemohon hibah yaitu pajak atas bea perolehan hak atas tanah dan bangunan berdasarkan Undang-Undang No. 21 Tahun 2001.

Pembuatan akta perjanjian hibah tersebut juga telah memperoleh persetujuan ahli waris dari pemberi kuasa. Sesuai dengan isi perjanjian hibah bahwa perbuatan hukum pengikatan hibah tersebut disaksikan, diketahui, dan disetujui oleh saudara kandung dari pihak pemberi hibah yang dalam hal ini saudara kandung pemberi hibah adalah ahli waris. Sehingga pihak-pihak dari pemberi hibah, penerima hibah, serta ahli waris telah mengetahui hak-hak dan kewajiban-kewajiban tentang hibah yang dilakukan dan terikat dalam suatu bentuk perjanjian hibah.

Oleh karena itu akta perjanjian hibah di notaris diikuti kluasula kuasa mutlak itu sah berdasarkan dasar hukum yang mengatur tentang kuasa mutlak dalam peralihan hak atas tanah dalam proses pembuatan akta hibah PPAT.

\section{PENUTUP \\ Kesimpulan}

Kuasa mutlak tersebut merupakan bagian dari perjanjian pokoknya tersebut. Kuasa mutlak tersebut tidak dapat dibatalkan secara sepihak sebelum perjanjian pokoknya dibatalkan. Oleh karenanya kuasa yang merupakan bagian dari perjanjian tersebut adalah sebagai jaminan kepastian hukum telah terjadi perbuatan hukum dalam perjanjian hibah dan menjamin kepastian hukum bagi menerima hibah bilamana pihak pemberi hibah meninggal dunia, penerima kuasa tetap dapat menjalankan proses pembuat akta hibah di hadapan PPAT.

Kedudukan akta perjanjian hibah yang diikuti klausula kuasa mutlak dalam pemindahan hak atas tanah yang dibuat dihadapan Notaris tidak pernah dilarang oleh undang-undang asalkan menjadi satu kesatuan dengan akta perjanjian hibah untuk menghindari terjadinya masalah di kemudian hari. Sehingga akta perjanjian tersebut tidak termasuk larangan yang terdapat dalam Instruksi Menteri Dalam Negeri Nomor 14 Tahun 1982.

\section{Rekomendasi}

Pencantuman kuasa mutlak pada perjanjian hibah masih dibutuhkan oleh para pihak dalam pembuatan perjanjian tersebut. Hal tersebut untuk menjaga kepentingan para pihak dapat terpenuhi hingga proses peralihan hak atas tanah tersebut selesai. Dalam 
membuat akta perjanjian yang menggunakan kuasa mutlak Notaris/PPAT harus lebih berhati-hati dalam melihat kepentingan para pihak. Notaris/PPAT dalam melaksanakan tugas jabatannya berkewajiban untuk memberikan penjelasan informasi yang lengkap dan jelas mengenai akibat-akibat hukum dari tiaptiap perjanjian yang dibuatnya, serta dalam hal memberikan pelayanan dan jasa kepada pihak-pihak sejauh mungkin menghindarkan terjadinya sengketa di kemudian hari.

Sebaiknya BPN terlebih dahulu memeriksa kebenaran akta hibah dan kronologis pembuatan akta tersebut sehingga para pihak tidak dirugikan dengan penolakan pihak BPN. Serta disarankan kepada pihak BPN untuk memeriksa kembali dengan teliti aturan yang berlaku sehingga mengetahui apakah penolakan tersebut harus dilakukan.

\section{DAFTAR PUSTAKA}

\section{Peraturan Perundang-undangan:}

Kitab Undang-Undang Hukum Perdata.

Undang-undang Nomor 5 Tahun 1960 tentang Peraturan Dasar Pokok-Pokok Agraria.

Undang-Undang Nomor 2 Tahun 2014 tentang Perubahan Atas Undang-Undang Nomor 30 Tahun 2004 tentang Jabatan Notaris.

Peraturan Pemerintah Nomor 24 Tahun 1997 tentang Pendaftaran Tanah.

Peraturan Pemerintah Republik Indonesia Nomor 37 Tahun 1998 tentang Peraturan Jabatan Pejabat Pembuat Akta Tanah.

Yurisprudensi Mahkamah Agung (MA) Putusan MA tanggal 16 Desember 1967 No. 731 K/Sip/1975 dan Putusan MA tanggal 17 Nopember 1987 No. $3604 \mathrm{~K} / \mathrm{Pdt} / 1985$.

Instruksi Menteri Dalam Negeri Nomor 14 Tahun 1982 tentang Larangan Penggunan Kuasa Mutlak.

Surat Direktur Jendral Agraria No. 584/493/AGR tanggal 31 Maret 1982.

\section{Buku:}

Adam, Muhammad, 1985, Asal Usul dan Sejarah Akta Notarial, Bandung: Sinar Baru.

Asshiddiqie, Jimly, 2003, "Independensi dan Akuntabilitas Pejabat Pembuat Akta Tanah," Jakarta: Renvoi.

Badrulzaman, Mariam Darus, 2001, Kompilasi Hukum Perikatan, Bandung: Citra Aditya Bakti.
Boediarto, Ali, 1990, "Putusan Badan Peradilan", Majalah Varia Peradilan, Edisi Oktober, Jakarta.

Budiono, Herlien, 2008, Kumpulan Tulisan Hukum Perdata di Bidang Kenotariatan, Bandung: Citra Aditya Bakti.

Hatta, Sri Gambir Melati, 1999, Beli Sewa Sebagai Perjanjian Tak Bernama: Pandangan Masyarakat dan Sikap Mahkamah Agung Indonesia, Bandung: Alumni.

Kumpulan Yurisprudensi Mahkamah Agung Republik Indonesia, Putusan P.N. Bandung No.75/1972/ Perd/PTN, tertanggal 20 November 1972.

Marzuki, Peter Mahmud, 2006, Penelitian Hukum, Jakarta: Kencana.

Prajitno, A.A. Andi, 2013, Pengetahuan Praktis Tentang Apa dan Siapa PPAT (Pejabat Pembuat Akta Tanah), Malang: Selaras.

Raharjo, Handri, 2009, Hukum Perjanjian di Indonesia, Yogyakarta: Pustaka Yustisia.

Salim H.S., 2003, Hukum Kontrak, Jakarta: Sinar Grafika.

Sangsun, Florianus SP., 2007, Tata Cara Mengurus Sertifikat Tanah, Jakarta: Visimedia.

Sjaifurrachman, 2011, Aspek Pertanggungjawaban Notaris Dalam Pembuatan Akta, Bandung: Mandar Maju.

Subekti, R., 1979, Hukum Perjanjian, Jakarta: Intermasa.

, 1982, Aneka Perjanjian, Bandung: Alumni. , 1982, Aneka Perjanjian, Cet. 5, Bandung: Alumni.

\section{Skripsi/Tesis:}

Hendarsanto, Prastowo, Studi Perbandingan tentang Hubungan Hibah dengan Waris menurut Kompilasi Hukum Islam dan Kitab UndangUndang Hukum Perdata, Semarang: Universitas Diponegoro Tesis, available from URL: pdflink. blogspot.co.id/2012/12/studi-perbandingantentang-hubungan.html, diakses tanggal 01 Oktober 2015.

Khairandy, Ridwan, 2003, Iktikad Baik Dalam Kebebasan Berkontrak, Program PascaSarjana Fakultas Hukum Universitas Indonesia, Jakarta. Utama, Ronny, Tesis tentang Larangan Kuasa Mutlak Notariil, Semarang: Universitas Diponegoro, Tesis, available from http://core.ac.uk/download/ pdf/11715805.pdf, diakses tanggal 11 Oktober 2015. 